\title{
Upaya Pemberantasan Kartel dengan Pemberlakuan Leniency Program
}

\author{
Marifa Anandita Sari \\ Magister Hukum, Fakultas Hukum, Universitas Indonesia \\ Email:marifanandita@gmail.com
}

\begin{abstract}
This research is intended to explain whether the leniency program can be applied in Indonesia. In accordance with Law No. 5 of 1999, Indonesia currently has not implemented a leniency program in terms of cartel empowerment efforts. The Leniency Program is expected to be a solution to reduce and be able to open a veil of cartel that has been difficult to prove. Research method in this paper using normative method with the analysis of regulations and comparative law. The results of this study show that the leniency program that has been launched by the developed state can reduce and open cartel cases significantly. Even so, the application needs to be considered according to the needs of the country. In a number of other studies, developing countries that apply the leniency program only duplicate those that have been implemented by other countries so that their application is less effective. The amendment to the competition law is needed to applied leniency program
\end{abstract}

\section{Keywords: Leniency Program, Cartel, Antitrust Law}

Abstrak. Penelitian ini bertujuan untuk menjelaskan apakah leniency program dapat diterapkan di Indonesia. Sesuai dengan Undang-Undang No. 5 Tahun 1999 saat ini Indonesia belum menerapkan leniency program dalam hal upaya pemberatasan kartel. Leniency program diharapkan dapat menjadi solusi untuk mengurangi dan dapat membuka tabir kartel yang selama ini sulit dibuktikan. Metode penelitian yang digunakan adalah metode normative dengan analisa peraturan perundang-undangan dan perbandingan hukum. Hasil dari penelitian ini menunjukkan bahwa leniency program yang telah dijalankan negara lain dapat mengurangi dan membuka kasus kartel secara signifikan. Meskipun begitu, dalam penerapannya perlu diperhatikan sesuai dengan kebutuhan negara. Dalam beberapa penelitian lain, negara berkembang yang menerapkan leniency program cenderung hanya menduplikasi yang sudah diterapkan negara lain sehingga penerapannya kurang efektif. Maka bila dalam perubahan undang-undang persaingan usaha akan dimasukkan leniency program, diperlukan hal-hal yang menunjang kesuksesan program seperti denda yang sepadan dengan perbuatannya.

\section{Kata Kunci: Leniency Program, Kartel, Hukum Persaingan Usaha}

\section{PENDAHULUAN}

Setiap Pelaku Usaha selalu mencari cara untuk mendapatkan keuntungan sebesarbesarnya dalam melakukan usaha. Upaya yang dapat dilakukan untuk mendapatkan keuntungan dapat dilakukan dengan marketing yang baik, meingkatkan kualitas produk sehingga memiliki reputasi yang baik sampai melakukan perbuatan yang dilarang dalam peraturan perundangundangan. Perbuatan yang dilarang sebagaimana dalam Undang-Undang No. 5 Tahun 1999 tentang Larangan Praktek Monopoli dan Persaingan Usaha Tidak Sehat. Adapun tujuan dari undang-undang persaingan dijelaskan dalam Pasal 3 UU No. 5 Tahun 1999 yaitu: a. menjaga kepentingan umum dan meningkatkan efisiensi ekonomi nasional sebagai salah satu upaya untuk meningkatkan kesejahteraan rakyat;

b. mewujudkan iklim usaha yang kondusif melalui pengaturan persaingan usaha yang sehat sehingga menjamin adanya kepastian kesempatan berusaha yang sama bagi pelaku usaha besar, pelaku usaha menengah, dan pelaku usaha kecil;

c. mencegah praktek monopoli dan atau persaingan usaha tidak sehat yang ditimbulkan oleh pelaku usaha; dan

d. terciptanya efektivitas dan efisiensi dalam kegiatan usaha. 
Adanya undang-undang mengenai persaingan usaha dianggap dapat memajukan perekonomian negara. Karena dengan adanya kontrol terhadap pasar, maka perekonomian yang diciptakan oleh pasar juga akan sehat. Hal ini sejalan dengan tujuan terciptanya undang-undang persaingan usaha yaitu dapat menciptakan perekonomian yang sehat dan menjaga persaingan yang sehat. Persaingan yang sehat dalam pasar akan menguntungkan baik bagi pelaku usaha maupun konsumen.

Undang-undang persaingan usaha mengkategorikan perbuatan, perjanjian dan kegiatan lainnya yang dikhawatirkan dapat merusak persaingan di pasar. Kartel merupakan salah satu perjanjian yang dilarang dalam UU No. 5 Tahun 1999. Perjanjian pada kartel dapat dilakukan antara pelaku usaha yang merupakan salah satu dari jenis perjanjian yang dilarang dalam Undang-Undang No. 5 Tahun 1999. Kartel sendiri merupakan kerjasama sejumlah perusahaan yang bersaing untuk mengkoordinasi kegiatannya sehingga dapat mengendalikan jumlah produksi dan harga suatu barang dan atau jasa untuk memperoleh keuntungan diatas tingkat keuntungan yang wajar. Kartel akan memaksa konsumen membayar lebih mahal suatu produk, baik itu barang mewah maupun barang-barang yang biasa diperlukan masyarakat seperti obat-obatan dan vitamin.

Dalam Pasal 11 dijelaskan bahwa Pelaku usaha dilarang membuat perjanjian, dengan pelaku usaha pesaingnya, yang bermaksud untuk mempengaruhi harga dengan mengatur produksi dan atau pemasaran suatu barang dan atau jasa, yang dapat mengakibatkan terjadinya praktek monopoli dan atau persaingan usaha tidak sehat. Kartel merupakan termasuk dalam perjanjian yang dilarang karena para anggota kartel pada dasarnya tidak memberikan kesempatan bagi pelaku usaha di luar anggotanya untuk bersaing secara terbuka. Hal ini didasarkan dengan pertimbangan atau kalkulasi ekonomi bahwa semakin banyak competitor, kemungkinan untuk memperoleh konsumen, menguasai pasar atau kesempatan mendapatkan keuntungan akan semakin terbatas. Semakin dikit pesaing maka tingkat persaingan akan lebih kecil dan untuk membuat kesepakatan antar pelaku usaha pun akan lebih mudah.
Suatu perbuatan dapat dikategorikan dalam kartel bila didalamnya terdapat perjanjian atau kolusi. Ada dua bentuk kolusi dalam kartel, yaitu:

a. Kolusi eksplisit, dimana para anggota mengkomunikasikan kesepakatan mereka secara langsung yang dapat dibuktikan dengan adanya dokumen perjanjian, data mengenai audit bersama, kepengurusan kartel, kebijakan- kebijakan tertulis, data penjualan dan data-data lainnya.

b. Kolusi diam-diam, dimana pelaku usaha anggota kartel tidak berkomunikasi secara langsung, pertemuan-pertemuan juga diadakan secara rahasia. Biasanya yang dipakai sebagai media adalah asosiasi industri, sehingga pertemuan-pertemuan anggota kartel dikamuflasekan dengan pertemuan- pertemuan yang legal seperti pertemuan asosiasi. Bentuk kolusi yang kedua ini sangat sulit untuk dideteksi oleh penegak hukum. Namun pengalaman dari berbagai negara membuktikan bahwa setidaknya $30 \%$ kartel adalah melibatkan asosiasi.

Indonesia menerapkan asas rule of reason pada pelanggaran kartel. Sehingga bila ditemukan adanya perbuatan kartel, tidak mutlak dikenakan sanksi, melainkan perlu dilihat alasan pembenar dari perbuatan kartel tersebut. Meskipun Indonesia menerapkan asas rule of reason, dalam kenyataannya perbuatan kartel dalam bentuk apapun dapat merugikan konsumen atau produsen. Hal ini lah yang menjadikan kartel sangat dilarang untuk dilakukan. Menurut Munrokhim Misanam ancaman kartel lebih bahaya dari korupsi, sebab selain nilai yang dikeruk dari masyarakat sangat besar, masyarakat juga tidak sadar akan kerugian tersebut.

Alat bukti yang dapat digunakan dalam pembuktian perbuatan Kartel dijelaskan dan ditetapkan oleh KPPU Peraturan Komisi Pengawas Persaingan Usaha Tentang Pedoman Pelaksanaan Pasal 11 Tentang Kartel Berdasarkan Undang-Undang Nomor 5 Tahun 1999 Tentang Larangan Praktek Monopoli dan Persaingan Usaha Tidak Sehat. Dari macammacam alat bukti yang dijelaskan dalam Pedoman Pasal 11, alat bukti yang diperlukan 
pada pembuktian kartel merupakan hard evidence. Sebaliknya alat bukti yang muncul pada perbuatan Kartel bukan merupakan hard evidence. Pelaku usaha akan berhat-hati dan secara rahasia dalam melakukan perbuatan kartel dan pastinya dengan tidak menyimpan alat bukti yang dapat digunakan sebagai pembuktian perbuatan Kartel dikemudian hari. Hal ini menjadikan pengumpulan alat bukti dalam hal pembuktian perbuatan kartel masih sulit dilakukan. Kerahasian inilah yang menjadikan salah satu kesulitan dalam memberantas kartel. Karena Kartel merupakan perbuatan ilegal, alat bukti pun sulit ditemukan oleh lembaga yang berwenang dan menyebabkan kartel masih terus dilakukan.

Kerahasian yang terdapat dalam perbuatan kartel menjadikan pembuktian apabila terdapat perbuatan kartel sulit dilakukan. Hal ini dikarenakan untuk membuktikan terjadinya pelanggaran terhadap ketentuan dalam UndangUndang Nomor 5 Tahun 1999, KPPU harus menganalisis dan membuktikan bahwa unsurunsur dari masing-masing pasal telah terpenuhi. Dalam kasus dugaan pelanggaran UndangUndang Nomor 5 Tahun 1999, baik Pasal 5, Pasal 9, maupun Pasal 11, mensyaratkan pemenuhan unsur perjanjian untuk membuktikan bahwa telah terjadi pelanggaran atas ketentuan pasal-pasal tersebut. Namun demikian karena kartel biasanya dibentuk dan dilakukan secara rahasia maka pembuktian keberadaan perjanjian kartel menimbulkan permasalahan. KPPU sulit untuk menemukan adanya perjanjian tertulis maupun dokumen lain yang secara eksplisit berisi kesepakatan mengenai harga, wilayah pemasaran, maupun produksi atas barang dan/atau jasa di antara pelaku usaha.

Untuk mengurangi atau memberantas perbuatan kartel terdapat suatu program yang telah diberlakukan di negara-negara lain yang disebut leniency program. Leniency program adalah suatu kebijakan yang menjelaskan bahwa bagi anggota kartel yang terlebih dahulu melaporkan terkait perjanjian kartel tersebut tidak akan dikenakan sanksi akan perbuatan kartel tersebut. Leniency program ini memiliki kemiripan dengan whistle-blower yaitu siapa yang melaporkan duluan tidak akan dikenakan sanksi. Pada beberapa penelitian leniency program dianggap dapat mengurangi pelanggaran kartel. Peraturan persaingan usaha yang tradisional mampu memberikan efek atas pengurangan kartel, namun tidak dapat sepenuhnya. Berdasarkan penelitian yang dilakukan Hinloopen dan Soetvent pengaturan persaingan usaha dengan leniency program menghasilkan kesuksesan yang lebih besar. Dengan adanya leniency program ini berdampak penurunan harga rata-rata, menurunkan kartel dan mencegah adanya kemungkinan kartel terbentuk kembali sekaligus memiliki efek pencegahan kartel akan terjadi lebih besar dibandingkan pengaturan persaingan usaha tradisional.

Indonesia belum memberlakukan leniency program sebagai upaya pemberantasan kartel. Meskipun dianggap efektif dalam mengurangi kartel, dalam Undang-Undang No. 5 Tahun 1999 belum mengatur mengenai leniency program dalam upaya mengurangi kartel. Pada Peraturan Komis Pengawas Persaingan Usaha No. 1 Tahun 2010 tentang Tata Cara Penanganan Perkara Praktik Monopoli dan Persaingan Usaha Tidak Sehat, sumber perkara pada KPPU dapat berasal dari laporan atau inisiatif dari komisi bila terdapat dugaan adanya pelanggaran yang terdapat dalam Undang-Undang Sehingga dalam tulisan ini lebih lanjut akan dibahas mengenai leniency program, keuntungan dan kekurangannya serta bisakah leniency program berlaku di Indonesia sebagai salah satu upaya mengurangi pelanggaran kartel.

\section{METODE PENELITIAN}

Pada penelitian ini tipe penelitian yang digunakan adalah penelitian normative. Penelitian dilakukan dengan menelaah Peraturan Perundang-Undangan yang berkaitan dengan hukum persaingan usaha dan pemberantasan kartel. Selain analisa berdasarkan peraturan perundang-undangan, penelitian juga dilakukan dengan perbandingan hukum yaitu mengenai pemberlakuan leniency program di negara lain. Jenis data yang digunakan pada penelitian ini adalah data sekunder yaitu data yang didapatkan dari bahan pustaka. Analisis data yang digunakan dalam penelitian ini merupakan analisis kualitatif. Analisis kualitatif merupakan analisis yang dilakukan pada data yang tidak dapat 
dihitung, bersifat kasus-kasus yang dipelajari secara utuh.

\section{HASIL DAN PEMBAHASAN}

\section{Sejarah dan Pemberlakuan Leniency Program}

Leniency program merupakan suatu pengaturan yang dibuat untuk memberikan insentif pada anggota kartel. Cara kerja dari pengaturan ini adalah Pelaku Usaha atau oknum yang terlibat dengan inisiatifnya sendiri melaporkan dan mengakui keikutsertaannya dalam kartel. Penghargaan yang diberikan pada pihak yang pertama kali melaporkan atau whistle-blower pertama merupakan pengurangan yang besar atau pengurangan secara penuh atas hukuman. Insentif juga dapat diberikan pada whistle-blower lain yang memberikan bukti yang mendukung kepada lembaga yang berwenang. Pemberlakuan dari leniency program ini membuka tabir konspirasi kartel yang mungkin atau sedang terjadi namun tidak dapat terdekteksi dan memastikan bahwa investigasi yang dilakukan lebih efisien dan efektif.

Pemberlakuan leniency program mulai dilaksanakan sejak tahun 1978 di Amerika Serikat. Namun, kesuksesan dari leniency program baru dapat dirasakan setelah lembaga persaingan usaha merevisi "Corporate Leniency Programme" pada tahun 1993. Ketentuan leniency program yang baru memberikan keuntungan yang signifikan pada tahun pertama diberlakukan. Revisi dibuat agar lebih memudahkan dan menarik perusahaan untuk melaporkan kepada lembaga persaingan. Terdapat 3 perubahan besar pada leniency program Amerika Serikat yaitu:

a. Leniency program otomatis dapat berlaku pada perusahaan dengan diberikan jaminan tidak ada investigasi sebelumnya

b. Leniency program terus berlaku meskipun investasi sedang dilakukan atau telah dilakukan

c. Seluruh pegawai, direksi, dan petugas yang melaporkan terlebih dahulu berkaitan dengan perusahaannya akan dilindungi atau terbebas dari tuntutan pidana.

Menurut perubahan Corporate Leniency Programme pada tahun 1993, pelaku atau anggota kartel dapat terbebas dari sanksi criminal dengan dua cara, Pertama, perusahaan berkolusi dengan meyampaikan informasi sebelum investigasi dimulai. Kedua, perusahaan dapat memberikan informasi bila lembaga persaingan usaha telah memulai investigasi namun belum menemukan bukti yang dapat digunakan. Dengan perubahan-perubahan tersebut lembaga persaingan usaha dapat membuka dan berhasil mengakhiri kasus-kasur kartel di Amerika Serikat berkat revisi leniency program yang dilakukan pada tahun 1993.

Selain Amerika Serikat, selanjutnya pada tahun 1996 Uni Eropa memperkenalkan regulasi baru yang serupa dengan leniency program yaitu memberikan keringanan yang cukup besar pada perusahaan yang bekerjasama dengan lembaga persaingan usaha sebelum penyelidikan dimulai. Keringanan dapat diberikan bila perusahaan bekerjasama dengan memberikan bukti berupa perjanjian terhadap keikutsertannya dalam kartel tersebut. Uni Eropa mengadopsi leniency program pada tahun 1996 dan selanjutnya direvisi pada tahun 2002. Negara anggota Uni Eropa seperti Belgium memberlakukan pada tahun 1999, Ceko, Perancis, Irlandia, Slovakia, Belanda, Swiss, dan Inggris telah mengadopsi pada tahun 2002. Pada tahun 2011 seluruh negara Uni Eropa terkecuali Malta telah mengadopsi leniency program

Sampai tahun 2016, terdapat 50 yurisdiksi yang sudah memberlakukan leniency program. Diantara negara Timur Tengah dan Afrika, Mesir dan Tunisia merupakan yang paling terbaru dalam memberlakukan leniency program dalam hukum persaingan usahanya. Setiap negara pada umumnya menerapkan peraturan yang sama yaitu pemberian insentif pada perusahaan atau pihak pertama yang melaporkan adanya perjanjian kartel. Meskipun begitu terdapat perbedaan-perbedaan detail pada seberapa besar insentif yang diberikan dan system penerapan leniency program di masing-masing negara. Contoh pada negara Algeria, Jordan dan Maroko terdapat pemberlakuan yang berbeda yaitu memberikan keringan hukuman pada perusahaan yang berpartisipasi secara penuh atas investigasi dugaan kartel di luar pengadilan sebelum kasus tersebut dilanjutkan atau dimulai persidangannya di pengadilan.

Pemberlakuan dari leniency program ini terbukti mampu mengurangi kartel. Hasil laporan 
dan penelitian pada negara-negara yang telah memberlakukan leniency program menjelaskan bahwa leniency program mampu mengurangi dan membuka kasus kartel dalam waktu singkat. Salah satu negara yang mendapatkan keberhasilan pada pemberlakuan leniency program dalam waktu singkat adalah Korea Selatan. Leniency program mulai diberlakukan pada tahun 1997. Kesuksesan Korea Selatan baru dirasakan setelah revisi yang dilakukan pada tahun 2005. Dalam jangka waktu tahun 20052011, dari 196 total kasus kartel 102 diantaranya merupakan leniency program. Dengan hasil tersebut leniency program di Korea Selatan telah dianggap sukses dalam mendeteksi adanya pelanggaran dalam waktu yang sangat singkat.

Dalam penelitian lain Miller (2009) yang menggunakan metode empiric dalam penelitian juga menunjukkan adanya dampak positif dari pemberlakuan leniency program pada prakteknya. Dilihat dari data kartel Amerika Serikat antara tahun 1985-2005 menunjukkan bahwa penemuan perjanjian kartel meningkat pada tahun 1993 setelah revisi dilakukan dan menurun secara drastic setelahnya. Uni Eropa juga sukses dalam pengadopsian leniency program yang menunjukan pemberian insentif tersebut mempercepat proses investigasi dalam dugaan pelanggaran kartel. Pemberian insentif pada leniency program tidak menyebakan ketidakseimbangan dalam hal pengaturannya. Justru sebaliknya Berdasarkan penelitianpenelitian tersebut pemberlakuan leniency program dengan benar akan memberikan keuntungan dalam rangka mengurangi dan membuka pelanggaran kartel.

\section{Pengaturan Kartel di Indonesia}

Tugas dan wewenang dari KPPU telah dituangkan dalam Undang-Undang No. 5 Tahun 1999. Pasal 35 menjelaskan bahwa salah satu tugas KPPU adalah melakukan penilaian terhadap perjanjian yang dapat mengakibatkan terjadinya praktek monopoli dan persaingan usaha tidak sehat yang salah satunya adalah kartel sesuai dengan Pasal 11 UU No. 5 Tahun 1999. Kartel merupakan salah satu dari perjanjian dilarang yang tertuang dalam UndangUndang No. 5 Tahun 1999 sehingga KPPU memiliki tugas untuk memeriksa apabila ada kegiatan yang mencurigakan yang dapat diduga perbuatan kartel.

Salah satu upaya KPPU dalam memberantas kartel adalah selain dengan memberikan penilaian dan memulai pemeriksaan sendiri, KPPU juga dapat menerima laporan dari masyarakat atau pelaku usaha lain bila diduga adanya kegiatan yang mengakibatkan praktek monopoli dan persaingan usaha tidak sehat termasuk kartel. Namun, konsep pelaporan ini bukanlah seperti leniency program, melainkan laporan biasa bahwa adanya persaingan tidak sehat yang terjadi di pasar. Pelapor baik pihak yang terlibat atau tidak dalam kegiatan tersebut tidak mendapatkan keuntungan atau intensif apapun dari laporannya. Berdasarkan laporan tersebut KPPU dapat memulai penyelidikannya terkait dengan persaingan usaha tidak sehat. Sehingga, bila mengacu pada konsep laporan tersebut Indonesia belum mengadopsi atau memberlakukan leniency program dalam pengaturan kartelnya, berbeda dengan negaranegara lain.

Berdasarkan laporan atau pemeriksaan yang dilakukan, KPPU memiliki wewenang untuk menilai suatu kegiatan yang dicurigai sebagai kartel dengan menggunakan indikasiindikasi dan pertimbangan dari segi ekonomi. Bila perjanjian tersebut terbukti merupakan perjanjian kartel terdapat 2 kemungkinan yang dapat terjadi tergantung dari adakah alasan pembenar dari perbuatan kartel tersebut. Indonesia menganut rule of reason dalam pengaturan kartel. Sehingga bila terbukti tidak akan secara mutlak dikenakan, melainkan akan dianalisa lebih lanjut apakah ada alasan pembenar dari perjanjian tersebut. Suatu perbuatan kartel dapat dinyatakan diterima (reasonable) atau tidak dapat diterima (unreasonable restraint) apabila:

a. Kegiatan para pelaku usaha menunjukkan tanda-tanda adanya pengurangan produksi atau naiknya harga. Apabila terdapat tandatanda tersebut, maka perlu diperiksa lebih lanjut

b. Apakah kegiatan para pelaku usaha bersifat naked (langsung) atau ancillary (tambahan). Kalau kegiatan tersebut bersifat naked, maka merupakan perbuatan yang melawan hukum. 
Sedangkan kalau ancillary, maka diperkenankan.

c. Para pelaku usaha mempunyai market power. Apabila para pelaku usaha mempunyai market power, maka terdapat kemungkinan mereka menyalahgunakan kekuatan tersebut.

d. Apakah terdapat hambatan masuk ke pasar yang tinggi. Walaupun para pelaku usaha mempunyai market power, akan tetapi kalau tidak ada hambatan masuk ke pasar yang berarti, maka akan mudah bagi pelaku usaha baru untuk masuk ke pasar.

e. Perbuatan para pelaku usaha apakah menciptakan efisiensi yang substansial dan menciptakan peningkatan kualitas produk atau servis atau adanya innovasi. Apabila alasan-alasan ini tidak terbukti, maka perbuatan tersebut adalah ilegal.

f. Perbuatan-perbuatan para pelaku usaha tersebut memang diperlukan untuk mencapai efisiensi dan inovasi. Artinya harus dibuktikan apakah perbuatan para pelaku usaha tersebut adalah alternatif terbaik untuk mencapai tujuan tersebut.

g. Perlu dilakukan adanya "balancing test" artinya perlu diukur keuntungan-keuntungan yang diperoleh dari perbuatan para pelaku usaha dibandingkan dengan akibat-akibat negatifnya. Apabila keuntungan yang diperoleh lebih besar dari kerugiannya, maka perbuatan tersebut dibenarkan.

\section{Potensi Pemberlakuan Leniency Program di Indonesia}

Secara yuridis, Pasal 5, Pasal 9 dan Pasal 11 UU Nomor 5 Tahun 1999 tentang Larangan Praktik Monopoli dan Persaingan Usaha Tidak Sehat yang membahas tentang larangan praktik kartel, tidak mengatur secara eksplisit mengenai leniency program, padahal program ini merupakan terobosan yang efektif untuk menangani kartel seperti yang sudah terbukti di berbagai negara. Meskipun begitu sampai saat ini KPPU belum menerapkan leniency program dalam menangani kasus-kasus kartel. Pemberlakuan leniency program di negaranegara lain terutama di negera maju terbukti dapat mengurangi dan membuka tabir dari kartel itu sendiri. Dina I Waked (2010) mengungkapkan pemberlakuan dari leniency program di negara berkembang dapat tidak efektif atau mengalami kegagalan karena beberapa hal. Ketentuan mengenai leniency program yang dibuat di negara berkembang kebanyakan hanyalah merupakan replika dari negara maju yang sudah memberlakukan. Karena hanya hasil dari replica negara lain, hukum yang dihasilkan pun tidak sesuai dengan kebutuhan yang diperlukan masing-masing negara. Adopsi hukum yang tanpa memperhatikan hal-hal yang terjadi di negaranya terbukti tidak efektif dalam memberantas kartel. Banyak dari negara berkembang yang mengadopsi hukum persaingan usaha bukan karena kebutuhan dari negara itu sendiri melainkan syarat yang harus dipenuhi dalam melakukan perdagangan antar regional. Dengan kesan terpaksa, hal tersebut merupakan salah satu alasan yang dapat menyebabkan pemberlakuan leniency program di suatu negara menjadi tidak efektif.

Agar suatu leniency program dapat berjalan sukses, maka ketentuan yang dibuat harus dapat menarik bagi pihak yang berpotensi menjadi whistle-blowers. Kejelasan, kepastian, dan prioritas merupakan hal yang sangat penting karena perusahaan biasanya akan melihat kondisi yang paling menguntungkan bagi mereka. Cara lain yang dapat dilakukan adalah dengan memaksimalkan insentif yang diberikan tidak hanya pada pelapor pertama melainkan pada pelapor lain juga. Insentif berupa pengurangan hukuman dilihat kurang menarik bagi perusahaan untuk melaporkan keterlibatannya atau informasi atas perbuatan kartel. OECD menjelaskan dalam pedomannya agar suatu leniency program dapat berjalan efektif diperlukan strategi dan perencanaan yang matang dalam pembuatan pengaturannya diantaranya:

a. Immunity

Imunitas ini diberikan kepada whistleblower pada sebagian besar leniency program apabila laporan dibuat disaat lembaga persaingan usaha tidak mengetahui adanya kartel terjadi ataupun ketika kartel sudah ditemukan namun buktinya belum cukup. Karenanya terdapat keuntungan yang lebih besar bagi perusahaan atau pihak yang melaporkan pertama.

b. Predictability 
Keringanan yang diberikan dapat diprediksi, maksudnya perusahaan atau pihak yang melaporkan dapat memprediksi keringanan dan keuntungan yang mereka dapatkan dengan melaporkan adanya perbuatan kartel tersebut. Prediksi keringanan hukuman bukanlah berdasarkan dari undang-undang yang tertulis saja, melainkan yurisprudensi atau hukuman dan sanksi lain yang dapat dikenakan bagi pelaku kartel. Bila pelaku dapat memprediksi keuntungan yang akan didapatkan maka mereka pun akan lebih tertarik untuk melaporkan perbuatan kartel tersebut.

c. Corporate Leniency and Leniency for Individuals

Dalam yurisdiksi tertentu, orang-perorangan saat ini mampu membuat kolusi bersama dengan perusahaan tempat mereka bekerja. Sanksi akibat partisipasi dalam kartel dapat berupa denda, penjara, larangan sementara atau selamanya untuk menjabat sebagai Direksi atau pegawai di perusahaan. Leniency program pada yurisdksi yang memberlakukan sanksi bagi individual biasanya memberikan imunitas kepada mereka agar dapat berkerja sama dengan lembaga sekaligus mendapatkan imunitas bagi individu dan perusahannya. Imunitas bagi individu ini diperlukan karena seorang individu dapat merubah keputusan yang dibuat oleh perusahaan untuk kepentingan pribadinya. Beberapa leniency program juga memperbolehkan individu untuk melapor dan bisa mendapatkan keringanan secara terpisah dari perusahaan tempat orang tersebut bekerja.

\section{d. Protection from private damage action}

Untuk menjaga identitas dari perusahaan maupun pribadi yang melaporkan perbuatan kartel penegak hukum dapat mengurangi syarat yang dapat merugikan pelapor dari perbuatan kartel tersebut akan informasi yang diberikan agar lembaga dapat menindaklanjuti laporan tersebut. Pengurangan ini dilakukan untuk menjaga identitas dan keamanan dari pelapor. Selain mengurangi syarat yang diperlukan beberapa lembaga persaingan usaha di negara-negara tertentu juga merahasiakan identitas perusahaan penerima leniency. Laporan diterima dalam bentuk lisan sehingga menjaga kerahasian dari identitas tersebut.

\section{e. Risk related to corruption}

Agar leniency program dapat berjalan dengan efektif, perlu dipastikan bahwa selama proses tidak aka nada tindak pidana korupsi terlibat di dalamnya. Dalam suatu kasus, pelaku usaha kelas tinggi berusaha untuk melakukan suap agar leniency tidak dapat diteruskan. Untuk mengadopsi leniency program negara harus memastikan bahwa tindak pidana korupsi tidak akan ada dalam pengungkapan perbuatan kartel.

Untuk mengurangi dan membuka adanya perjanjian kartel di Indonesia, maka pemerintah perlu merencanakan dengan matang strategi dan perubahan undang-undang ke arah yang lebih baik. Perubahan perlu dilakukan agar bila leniency program dimasukkan maka, ketentuan ini tidak menjadi sia-sia. Leniency program yang sukses juga harus disertai dengan tingginya sanksi dari perjanjian kartel. Dalam UU No.5/1999, sanksi denda bagi perusahaan yang terbukti kartel paling tinggi Rp25 miliar. Sebagai perbandingan, hasil kajian KPPU atas kasus kartel fuel surcharge terungkap potensi keuntungan kesepuluh maskapai terhukum bisa mencapai total Rp13 triliun. Dengan sanksi yang sangat lah kecil dibandingkan keuntungannya, para pelaku usaha memilih untuk mendapatkan keuntungan dari kartel. Sehingga perlu adanya kenaikan sanksi denda yang dikenakan bagi pelaku usaha yang melakukan perjanjian kartel.

\section{KESIMPULAN}

Leniency program sendiri merupakan suatu pengaturan yang dibuat untuk memberikan insentif pada anggota kartel yang dengan inisiatifnya sendiri melaporkan dan mengakui keikutsertaannya dalam kartel dan melanggar hukum persaingan usaha. Pemberlakuan dari leniency program ini membuka tabir konspirasi kartel yang mungkin atau sedang terjadi namun tidak dapat terdekteksi dan memastikan bahwa investigasi yang dilakukan lebih efisien dan efektif. Hasil laporan dan penelitian pada negaranegara yang telah memberlakukan leniency program mampu mengurangi dan membuka 
kasus kartel diantaranya dalam waktu singkat. Berdasarkan penelitian-penelitian tersebut pemberlakuan leniency program dengan benar akan memberikan keuntungan dalam rangka mengurangi dan membuka pelanggaran kartel.

Dalam Pasal 35 dijelaskan salah satu tugas KPPU adalah melakukan penilaian terhadap perjanjian yang dapat mengakibatkan terjadinya praktek monopoli dan persaingan usaha tidak sehat yang diatur dalam Pasal 4 sampai dengan Pasal 16. KPPU akan menilai apakah suatu kegiatan yang dicurigai tersebut dengan indikasiindikasi dan pertimbangan dari segi ekonomi. Sehingga bila tidak terbukti maka kartel tidak dapat dikenakan kepada para pelaku usaha, hal ini dikaarenakan Indonesia menganut prinisp rule of reason atas kartel. Saat ini Indonesia belum mengadopsi pengaturan leniency program. Agar suatu leniency program dapat berjalan sukses, maka ketentuan ini harus dapat menarik bagi pihak yang dapat menjadi whistleblowers OECD menjelaskan dalam pedomannya agar suatu leniency program dapat berjalan efektif diperlukan strategi dan perencanaan yang matang dalam pembuatan pengaturannya diantaranya terkait immunity, Predictability, Corporate Leniency and Leniency for Individuals, Protection from private damage action, Risk related to corruption.

\section{SARAN}

Undang-Undang No. 5 Tahun 1999 dilihat memerlukan adanya perubahan agar dapat mengikuti perkembangan zaman. Dunia bisnis merupakan dunia yang dinamis selalu ada inovasi dan perubahan baru. Agar dapat mengikuti Berdasarkan pembahasan sebelumnya, Indonesia masih belum mengadopsi leniency program dalam pengaturan kartelnya. Hal ini merupakan urgensi yang perlu segera di revisi pada Undang-Undang No 5 Tahun 1999 agar kartel tidak semakin merajalela di Indonesia.

Sebagai salah satu upaya pemberantasan kartel terdapat suatu konsep yaitu leniency program yang sudah diberlakukan di banyak negara lain. Pemberlakuan leniency program berhasil mengurangi dan memberantas kartel, sehingga perlu dipertimbangkan untuk diberlakukan juga di Indonesia. Konsep ini dapat menjadi salah satu alternatif pemberantasan kartel di Indonesia. Selain pemberlakuan leniency program juga harus diimbangi dengan sanksi yang sepadan agar tidak ada lagi pelaku usaha yang membuat perjanjian kartel dengan pelaku usaha lainnya. Dengan berbagai keuntungan dari pemberlakuan leniency program seharusnya Indonesia dapat memberlakukan ketentuan serupa untuk memberantas kartel.

\section{DAFTAR PUSTAKA}

Borell, Joan-Ramon, Juan Luis Jiménez, dan Carmen García. (2013). "Evaluating Antitrust Leniency Programs." Journal of Competition Law \& Economics, 10(1), 107136.

Choi, Yun Jeong dan Kyung Soo Hahn. (2014). "How Does Acorporate Leniency Program Affect Cartel Stability? Empirical Evidence from Korea." Journal Competition Law \& Economics, 10(4), 883-907.

Choi, Jay Pil dan Heiko Garlach. (2012). "Global Cartels, Leniency Programs and International Antitrust Cooperation." International Journal of Industrial Organization, 30, 528-540.

Fahmi Lubis, Andi. et. al. (2009). Hukum Persaingan Usaha Antara Teks dan Konteks. Jakarta: Komisi Pengawas Persaingan Usaha.

Fahmi Lubis, Andi. et.al. (2017). Edisi Kedua Hukum Persaingan Usaha Buku Teks. Jakarta: Komisi Pengawas Persaingan Usaha.

Hinloopen, Jeroen dan Sander Onderstal. (2014). "Going Once, Going Twice, Reported! Cartel Activity and The Effectiveness of Antitrust Policies in Experimental Auctions." European Economic Review, 70, 317-336.

Indonesia, Undang-Undang Larangan Praktek Monopoli dan Persaingan Usaha Tidak Sehat, Undang-Undang No. 5 Tahun 1999, LN No. 33 Tahun 1999, TLN No. 3817.

Indonesia, Komisi Pengawas Persaingan Usaha, Peraturan Komisi Pengawas Persaingan Usaha Tentang Pedoman Pelaksanaan Pasal 11 Tentang Kartel Berdasarkan Undang-Undang Nomor 5 Tahun 1999 Tentang Larangan Praktek Monopoli dan 
Persaingan Usaha Tidak Sehat, Nomor 4 Tahun 2010.

Minasam, Munrokhim. (2013). "Kartel Lebih Berbahaya dari Korupsi," Bertarung Melawan Kartel, Edisi 39.

Motta, Massimo dan Michele Polo. (2003). "Leniency programs and cartel prosecution." International Journal of Indutrial Organization, 21, 347-379.

Nindriani, Anita dan Pujiyono. (2020). "Prospek Leniency Program Sebagai Upaya Mengungkap Praktik Kartel dalam Hukum Persaingan Usaha di Indonesia." Jurnal Privat Law, Vol. VIII No. 1, 28-35.

OECD, "Using Leniency to Fight Hard Core Cartels." OECD Policy Brief. 2001

Soekanto, Soerjono. (2015). Pengantar Penelitian Hukum. Jakarta: UI Press.

Suharsil, dan Mohammad Taufik Makarao. (2010). Hukum Larangan Praktik Monopoli dan Persaingan Usaha Tidak Sehat di Indonesia. Bogor: Penerbit Ghalia Indonesia.

Silalahi, Udin dan Isabella Chyntia Edgina. (2017). "Pembuktian Perkara Kartel Di Indonesia Dengan Menggunakan Bukti Tidak Langsung (Indirect Evidence)," Jurnal Yudisial. Vol. 10 No. 3, 311-330.

UNCTAD MENA Programme, "Competition Guidelines: Leniency Programmes," UNCTAD with The Ministry for Foreign Affairs of Sweden.

Vereno Tarmes, M. "Bongkar Kartel dengan Leniency Program, https://www.hukumonline.com/berita/baca /lt4d81f77e90173/bongkar-kartel-denganleniency-program, diakses pada $21 \mathrm{Mei}$ 2020. 